\title{
Perbandingan Metode Hierarchical Cluster Analysis untuk Analisis Keragaman Hayati Trypanosoma evansi dari Indonesia Berdasarkan Profil Protein
}

\author{
(COMPARISON OF HIERARCHICAL CLUSTER ANALYSIS METHODS FOR \\ BIODIVERSITY ANALYSIS OF TRYPANOSOMA EVANSI FROM INDONESIA BASED \\ ON THE PROTEIN PROFILES)
}

\author{
Didik Tulus Subekti ${ }^{1 *}$, Ichwan Yuniarto ${ }^{2}$, Sulinawati $^{3}$ \\ ${ }^{1}$ Balai Besar Penelitian Veteriner Bogor, \\ Jl. RE Martadinata No.30, Ciwaringin, Bogor Tengah, \\ Kota Bogor, Jawa Barat 16124 \\ ${ }^{2}$ Balai Veteriner Banjarbaru, Jln. Ambulung 24, Loktabat Selatan, \\ Guntungmanggis, Landasan Ulin, Banjarbaru, Kalimantan Selatan 70712 \\ ${ }^{3}$ Balai Veteriner Lampung, Jl. Untung Suropati No.2, Labuhan Ratu, Kedaton, \\ Kota Bandar Lampung, Lampung 35142, Indonesia \\ "subekti@litbang.pertanian.go.id; subekti.vmd@lycos.com
}

\begin{abstract}
ABSTRAK
Hierarchical Clustering Analysis (HCA) telah lama diketahui bermanfaat untuk analisis keragaman hayati mikroorganisme berdasarkan profil protein dari SDS PAGE (sodium dodecyl sulphate polyacrylamide gel electrophoresis). Namun demikian, beragamnya metoda HCA akan menyebabkan keragaman hasil analisis yang berbeda satu dengan lainnya. Berdasar pertimbangan tersebut perlu dievaluasi untuk mengetahui metoda HCA yang paling sesuai untuk menggambarkan keragaman hayati berdasar profil protein isolat T.evansi dari Indonesia. Sebelas isolat yang berasal dari lokasi geografis berbeda dielektroforesis pada SDS PAGE. Selanjutnya profil protein dari SDS PAGE dikonversi menjadi data binari dan dianalisis menggunakan lima metoda HCA yaitu Average Linkage, Complete Linkage, Single Linkage, Ward Linkage, dan McQuitty Linkage. Data juga dianalisis dengan multidimensional scaling (MDS) dan densitogram. Hasil analisis menunjukkan bahwa dendrogram dengan metoda Ward Linkage merupakan hasil yang terbaik dan bersesuaian dengan densitogram, MDS dan mampu menggambarkan asal usul isolat secara geografis.
\end{abstract}

Kata-kata kunci: Trypanosoma evansi; keragaman hayati; dendrogram; profil protein; SDS PAGE

\begin{abstract}
Hierarchical Clustering Analysis (HCA) has long been known to be useful for the analysis of biodiversity of microorganisms based on SDSPAGE protein profile (sodium dodecyl sulfate polyacrylamide gel electrophoresis). However, varying methods of HCA consequently produce variability of analysis results and interpretations. Therefore, it is necessary to evaluate and further determine the most appropriate method which could described the biodiversity based on protein profiles of T.evansi isolates from Indonesia. Eleven isolates of T.evansi from different geographic locations were run on SDS PAGE. Furthermore, SDS PAGE protein profiles from eleven isolates were converted into binary data and analyzed using five different methods of HCA i.e. Average Linkage, Complete Linkage, Single Linkage, Ward Linkage and McQuitty Linkage, respectively.Data were also analyzed by multidimensional scaling (MDS) and densitogram. The analysis showed that the dendrogram constructed with Ward Linkage gives the best results and corresponding with densitogram, MDS and able to describe the geographical origins of isolates.
\end{abstract}

Keywords: Trypanosoma evansi; biodiversity; dendrogram; protein profile; SDS PAGE 


\section{PENDAHULUAN}

Surra merupakan penyakit hewan menular strategis di Indonesia yang mengakibatkan banyak kematian pada hewan terutama kuda dan kerbau. Surra disebabkan oleh protozoa darah yaitu Trypanosoma evansi (T.evansi). Di Indonesia, beberapa isolat T.evansi telah dilaporkan memiliki perbedaan galur berdasarkan pola parasitemia dan imunopatogenesis pada mencit (Subekti et al., 2013). Informasi serupa sebelumnya juga telah dilaporkan oleh De Menezes et al. (2004). Berdasarkan pola parasitemia dan imunopatogenesis pada mencit, di Indonesia dilaporkan terdapat 3 biotipe T.evansi (Subekti et al., 2013) sedangkan di Brazil dilaporkan terdapat 2 biotipe T.evansi (De Menezes et al., 2004). Hal demikian menunjukkan kemungkinan terdapat keragaman hayati pada T.evansi.

Indikasi keragaman hayati T.evansi juga dilaporkan berdasarkan profil protein yang dianalisis dengan SDS PAGE (sodium dodecyl sulphate polyacrylamide gel electrophoresis). Uche et al. (1992) telah melakukan penelitian untuk membandingkan profil protein isolat T.evansi dari Indonesia, Mesir, dan Yaman. Hasil penelitian tersebut menunjukkan bahwa isolat Indonesia memiliki sedikit perbedaan dengan isolat Mesir tetapi keduanya memiliki perbedaan yang besar dibandingkan isolat dari Yaman. Singh et al. (1995) juga telah melaporkan adanya keragaman profil protein pada membran sel dari 7 isolat T.evansi dari India bagian utara. Sebaliknya pada penelitian yang telah dilakukan oleh Laha et al. (2008) tidak menemukan adanya perbedaan profil protein antara tiga isolat T.evansi yang berasal dari kuda, kerbau, dan sapi dari India Timur. Adapun Sivajothi et al. (2015) melaporkan tidak ada variasi antigenik berdasarkan profil protein dari tiga isolat T.evansi dari anjing di Andhra Pradesh, India. Isolat T.evansi dari anjing tersebut berbeda profil proteinnya dengan isolat T.evansi dari sapi yang berasal dari daerah yang sama (Sivajothi et al., 2015).

Analisis keragaman hayati dari isolat T.evansi dapat menggunakan HCA (hierarchical cluster analysis) berdasarkan profil protein pada SDS PAGE. Delamare et al. (2002) telah menggunakan HCA dengan metoda Average Linkage untuk membandingkan perbedaan profil protein dari Aeromonas sp. pada tingkat spesies. Demikian pula halnya dengan Berber dan Berber (2006) yang membedakan beberapa isolat Bacillus sp. berdasarkan profil proteinnya baik pada tingkat spesies maupun galur. Berber dan Ekin (2008) juga telah menggunakan Average Linkage berdasarkan profil protein dari SDS PAGE untuk membedakan galur atau subtipe beberapa isolat Candida albicans. Selanjutnya Tahmourespour et al. (2013) telah berhasil membedakan galur Streptococcus mutans dari pasien yang bebas karies gigi dengan galur yang berasal dari penderita karies gigi yang peka serta membedakannya dengan Streptococcus mutans dari ATCC 35668.

Profil protein pada SDS PAGE merupakan gambaran distribusi pita protein berdasarkan pola sebaran pita protein dan kuantitas ekspresi pita protein yang diperlihatkan dengan ketebalannya. Profil protein tersebut memberikan informasi tentang berbagai protein di dalam sel suatu mikroorganisme yang melayani berbagai fungsi fisiologis terkait dengan lingkungan biologinya (Chae-Yoon et al., 2012). Dengan demikian profil protein akan memberikan gambaran menyeluruh beragam ekspresi protein dari mikroorganisme berkaitan dengan fisiologinya. Berdasarkan hal tersebut, maka analisis keragaman hayati berdasarkan profil protein akan lebih komprehensif dibanding berdasarkan satu atau dua jenis gen tertentu. Hal ini diperkuat pendapat Delamare et al. (2002) yang menyatakan bahwa denderogram dari data hasil RAPD (Random Amplified Polymorphic DNA) tidak bermanfaat untuk karakterisasi galur Aeromonas sp. pada tingkat spesies. Sebaliknya hasil yang diperoleh berupa dendrogram dari profil protein Aeromonas sp. berkorelasi dengan data biokimia dan genetik sehingga dapat digunakan untuk identifikasi dan taksonomi isolat Aeromonas sp. Chae-Yoon et al. (2012) berpendapat bahwa analisis pola protein Vibrio spp. dengan SDS PAGE dapat digunakan sebagai metoda identifikasi yang spesifik, cepat, dan sederhana.

Berdasar latar belakang tersebut, analisis keragaman hayati dari 11 isolat T.evansi dari beberapa daerah di Indonesia akan dilakukan menggunakan HCA berdasarkan profil protein pada SDS PAGE. Beberapa laporan umumnya hanya menggunakan satu jenis metoda untuk analisis HCA yaitu Average Linked. Salah satu kelemahan HCA adalah beragamnya metoda yang dapat menghasilkan hasil sangat berbeda satu dengan lainnya. Berdasarkan kondisi tersebut perlu dievaluasi untuk mengetahui metoda HCA yang paling sesuai untuk menggambarkan keragaman hayati berdasar 
profil protein isolat T.evansi yang berasal dari lokasi geografis berbeda di Indonesia.

\section{METODE PENELITIAN}

\section{Asal Isolat T.evansi}

Suspensi T.evansi yang digunakan dalam penelitian ini diperoleh dari Balai Besar Penelitian Veteriner Bogor (BBLITVET), Balai Veteriner Regional V Banjarbaru (BVET V), dan Bali Veteriner Regional III Lampung (BVET III). Suspensi T.evansi dari BBLITVET yaitu S13, S18, N371, N372, N375 dan N370. Adapun suspensi T.evansi dari BVET V adalah A13, A14, SPT sedangkan dari BVET III yaitu BGKU dan PLS (Tabel 1).

\section{Pemurnian T.evansi}

Suspensi trypanosoma dimurnikan dari darah mengikuti metode seperti yang dijelaskan oleh OIE (2012). Trypanosoma dimurnikan dengan teknik kromatografi pertukaran anion (anion exchange chromatography) menggunakan DEAE 52 (Whatman, USA) yang telah disuspensikan dalam PBS-G $1 \% \mathrm{pH}$ 8. Sekitar $8 \mathrm{~mL}$ suspensi DEAE dimasukkan ke kolom Poly-Prep ${ }^{\circledR}$ Chromatography (BioRad, Perancis)

Tabel 1. Ringkasan asal usul isolat T.evansi yang digunakan dalam penelitian ini

\begin{tabular}{ccl}
\hline $\begin{array}{c}\text { Kode } \\
\text { Isolat }\end{array}$ & $\begin{array}{c}\text { Tahun } \\
\text { isolasi }\end{array}$ & Asal Isolat (kabupaten/provinsi) \\
\hline S13 & 2014 & Kabupaten Serang - Provinsi Banten \\
S18 & 2014 & Kabupaten Serang - Provinsi Banten \\
A13 & 2013 & Kabupaten Hulu Sungai Utara (HSU) - Provinsi Kalimantan Selatan \\
A14 & 2014 & Kabupaten Hulu Sungai Utara (HSU) - Provinsi Kalimantan Selatan \\
SPT & 2014 & Kabupaten Kotawaringin Timur - Provinsi Kalimantan Tengah \\
BGKU & 2014 & Kabupaten Bengkulu Selatan - Provinsi Bengkulu \\
PLS & 2014 & Kabupaten Pesawaran - Provinsi Lampung \\
N370 & 2012 & Kabupaten Sumba Timur - Provinsi Nusa Tenggara Timur \\
N371 & 2012 & Kabupaten Sumba Timur - Provinsi Nusa Tenggara Timur \\
N372 & 2012 & Kabupaten Sumba Timur - Provinsi Nusa Tenggara Timur \\
N375 & 2012 & Kabupaten Sumba Timur - Provinsi Nusa Tenggara Timur \\
\hline
\end{tabular}

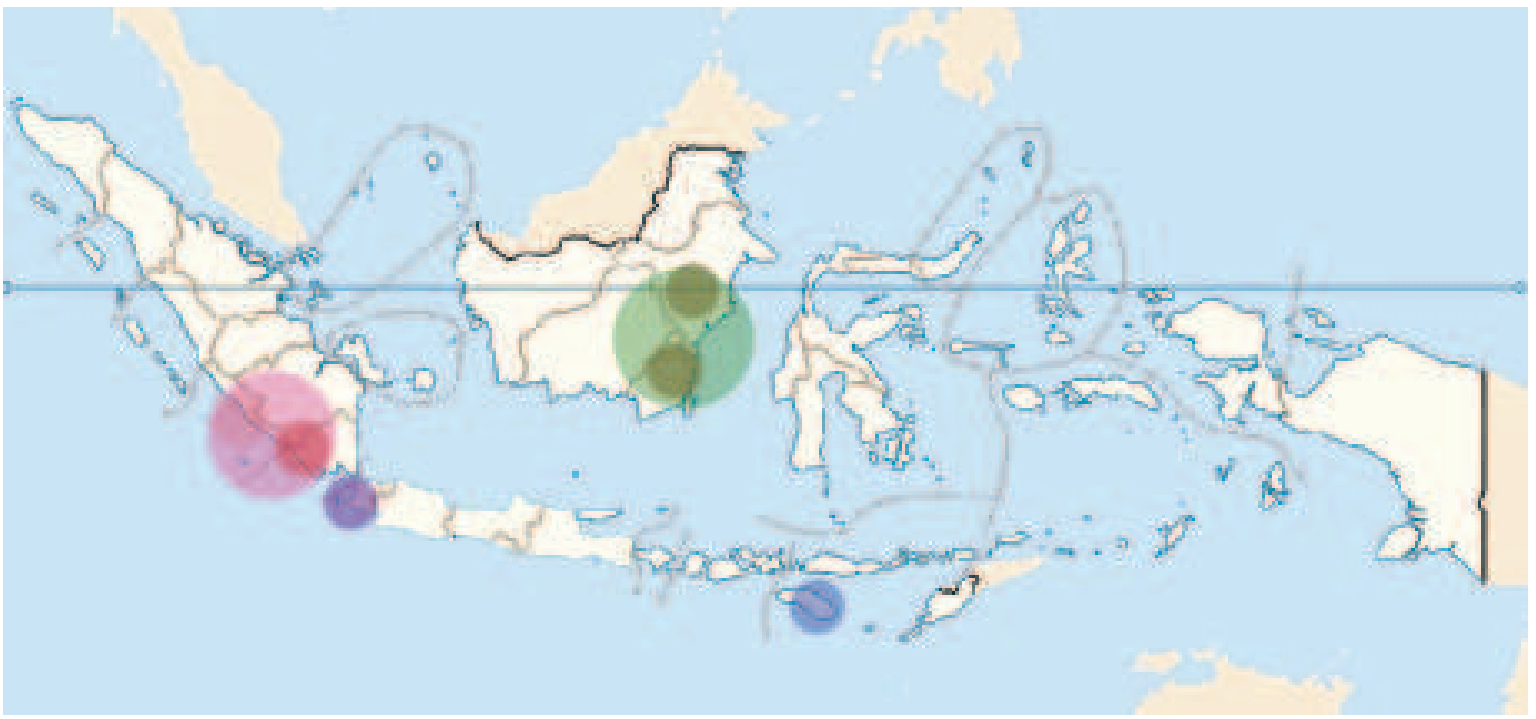

Gambar 1. Peta lokasi asal isolat T.evansi dari Indonesia yang digunakan dalam penelitian. Lingkaran biru: Sumba Timur provinsi Nusa Tenggara Timur (NTT), Lingkaran ungu: Serang provinsi Banten, Lingkaran Hijau: Kotawaringin Timur provinsi Kalimantan Timur dan Hulu Sungai Utara provinsi Kalimantan Selatan (Pulau Kalimantan), Lingkaran merah muda: Pesawaran provinsi Lampung dan Bengkulu Selatan provinsi Bengkulu (Pulau Sumatra). 
dan dibiarkan memadat. Setiap mililiter darah dituangkan secara hati-hati ke permukaan DEAE dan selalu dijaga agar tetap lembab menggunakan PBS-G 1\%. Trypanosoma murni dikumpulkan dalam tabung dan kemudian disentrifugasi pada kecepatan $3361 \times \mathrm{g}, 4^{\circ} \mathrm{C}$ selama 15 menit menggunakan Allegra $\mathbb{}(X-15 R$ Centrifuge (Beckman Coulter). Supernatan dibuang dan endapan diresuspensi dengan PBS $\mathrm{pH} 7$ yang mengandung aprotinin $0,11 \mathrm{TIU} / \mathrm{mL}$ (setara 140,4 KIU/mL). Suspensi kemudian disentrifugasi lagi pada kecepatan $3361 \mathrm{xg}, 4^{\circ} \mathrm{C}$ selama 15 menit. Langkah serupa diulang sampai 2 atau 3 kali. Terakhir, endapan kembali disuspensi dengan PBS-Aprotinin untuk proses isolasi protein.

\section{Isolasi dan Kuantifikasi Protein}

Isolasi protein dari suspensi trypanosoma dalam PBS-Aprotinin dilakukan dengan freezethawing secara berulang, sekitar 3 - 4 kali berturut-turut menggunakan nitrogen cair. Selanjutnya suspensi disentrifugasi pada kecepatan $10600 \mathrm{x}$ g selama 10 menit. Supernatan dipisahkan dari endapan, selanjutnya supernatan disebut sebagai TSA (trypanosome Soluble Antigen). Konsentrasi protein TSA diukur menggunakan metode Bradford menggunakan BioRad Protein Assay (BioRad, Perancis).

Secara ringkas, sebuah kurva standar dibuat menggunakan Bovine Serum Albumin (Sigma, USA), masing-masing pada konsentrasi $0 ; 0,5 ; 0,75 ; 1 ; 1,25 \mathrm{mg} / \mathrm{mL}$. Selanjutnya, masing-masing $10 \mu \mathrm{L}$ TSA dan protein standar dilarutkan dalam $190 \mu \mathrm{L}$ larutan Bradford. Setelah dihomogenisasi, $80 \mu \mathrm{L}$ dari setiap standar protein dan protein sampel (TSA) dimasukkan ke lempeng mikro (flat bottomed 96 well microplate, Nunc - Denmark) dan dibaca pada Multiskan EX Colorimeter Reader (Thermo Scientific, Finlandia) pada panjang gelombang $600 \mathrm{~nm}$. Nilai absorbansi kemudian dikonversi menjadi kadar protein.

\section{Elektroforesis pada Gel Poliakrilamida}

Protein trypanosoma (TSA) dari masingmasing isolat dielektroforesis pada SDS PAGE untuk membandingkan profil protein setiap isolat T.evansi. Sekitar $10 \mu \mathrm{g}$ TSA dari masingmasing isolat dicampur dengan $10 \mu \mathrm{L}$ buffer sampel (BioRad) menurut metoda Laemmli (Laemmli, 1970). Setiap sampel dimasukkan kedalam lajur dari gel (TGX ${ }^{\mathrm{TM}}$ pre cast gel $12 \%$, BioRad, Prancis) pada konsentrasi $10 \mu \mathrm{g}$ / lajur bersama dengan marka protein (RPN 800, Amersham Pharmacia). Elektroforesis dilakukan menggunakan Mini Protean (BioRad) pada 150 volt. Hasil elektroforesis kemudian divisualisasikan menggunakan Coomassie Brilliant Blue R250.

\section{Analisis Data}

Penentuan pita protein dan densitometri dilakukan dengan PhyElp 1.4 (Pavel dan Vasile, 2012). Pencocokan pita protein (Band Matching) pada hasil SDS PAGE menggunakan software PhyElp 1,4 yang selanjutnya diubah dalam bentuk matrik biner (Pavel dan Vasile, 2012). Matrik biner dari setiap isolat T.evansi dianalisis dengan berbagai metoda HCA (Hierarchical Cluster Analysis) menggunakan Minitab ver. 16. Metoda HCA yang digunakan adalah UPGMA (Unweighted Pair Group Method with Arithmetic Mean) atau Average Linkage, Complete Linkage atau Furthest Neighbour, Single Linkage atau Nearest Neighbour, Ward Linkage dan McQuitty Linkage. Analisis data dengan MDS (multidimensional scaling) menggunakan SPSS IBM Ver.21. Hasil analisis dengan HCA kemudian dicocokkan dengan MDS dan analisis visual menggunakan profil protein pada SDS PAGE dan densitometri untuk memilih metoda HCA yang paling sesuai.

\section{HASIL DAN PEMBAHASAN}

Profil protein dapat dikonversi menjadi densitogram sehingga dapat dibandingkan polanya dengan cara overlay/superimposed antar densitogram. Adapun multidimensional scaling (MDS) merupakan pemetaan distribusi isolat berdasarkan perbedaan pola pita proteinnya. Adapun HCA akan menghasilkan dendrogram berupa pembentukan pohon kemiripan pola pita protein dari isolat yang dipelajari. Masing-masing dendrogram dari beberapa metoda HCA akan dibandingkan dengan hasil analisis dari densitogram dan MDS.

Berdasarkan densitogram, isolat N372 sama dengan N370, PLS serupa dengan BGKU dan A13 serupa dengan SPT (Gambar 2.B). Bukti ini diperkuat dengan pengamatan profil protein dari SDS PAGE yang memperlihatkan hasil sejalan (Gambar 2.A). Demikian pula pada analisis dengan MDS, N372 tumpang tindih dengan N370, PLS berdekatan dengan BGKU 

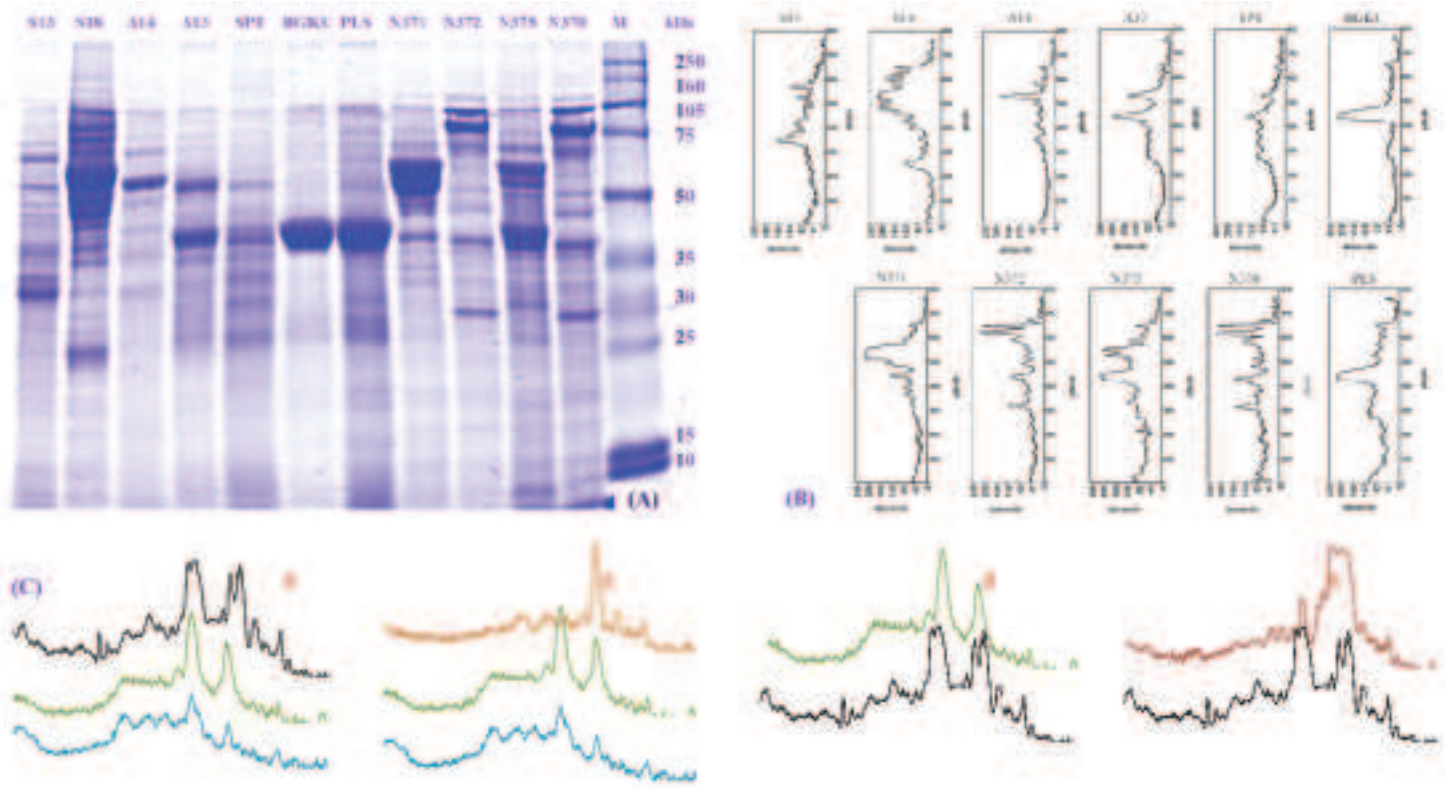

Gambar 2. Profil protein pada SDS PAGE dan Densitometri Profil Protein dari T.evansi

(A) Profil protein dari sebelas isolat T.evansi dari Indonesia pada SDS PAGE 12\% dengan pewarnaan Coomassie Brilliant Blue. (B) Densitometri profil protein dari sebelas isolat T.evansi dari Indonesia menggunakan software PhyElp 1,4. (C) Overlay/superimposed dari densitogram yang diperkirakan memiliki kemiripan < 65\%.Warna biru: densitogram isolat SPT, warna hijau: densitogram isolat A13, warna oranye: densitogram isolat A14, warna merah : densitogram isolat N371 dan warna hitam: densitogram isolat N375.
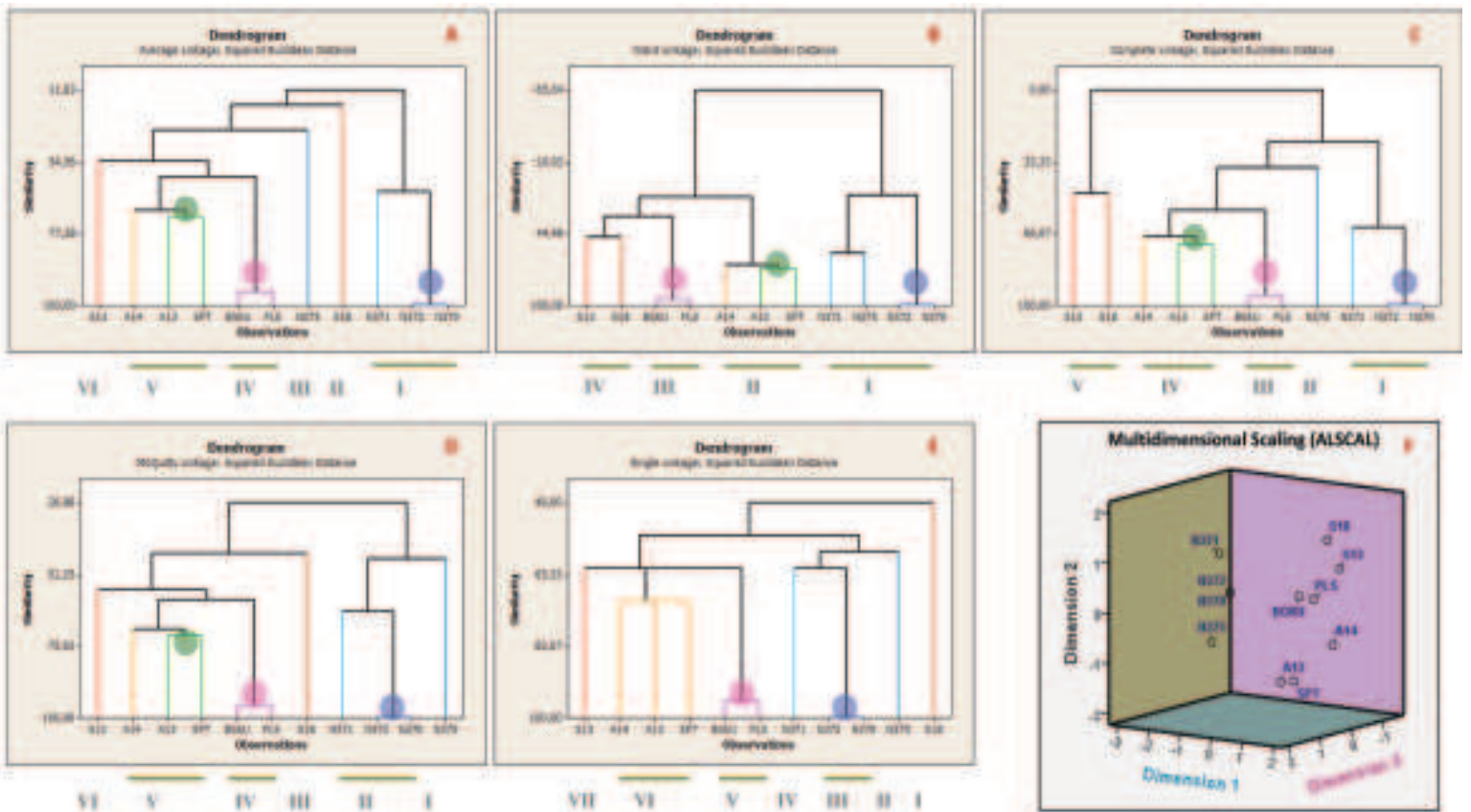

Gambar 3. Dendrogram dari enam metoda hirarchical cluster analysis dan multidimensional scaling yang menggunakan data profil protein pada SDS PAGE yang berasal dari sebelas isolat T.evansi di Indonesia.

Lingkaran biru, merah muda dan hijau menunjukkan kluster dari isolat T.evansi yang memiliki kemiripan profil protein $>70 \%$. Warna garis yang sama pada dendrogram menunjukkan bahwa isolat tersebut berada pada satu kluster pada tingkat kemiripan $72 \%$. I - VII menunjukkan kluster yang terbentuk dari dendrogram. 


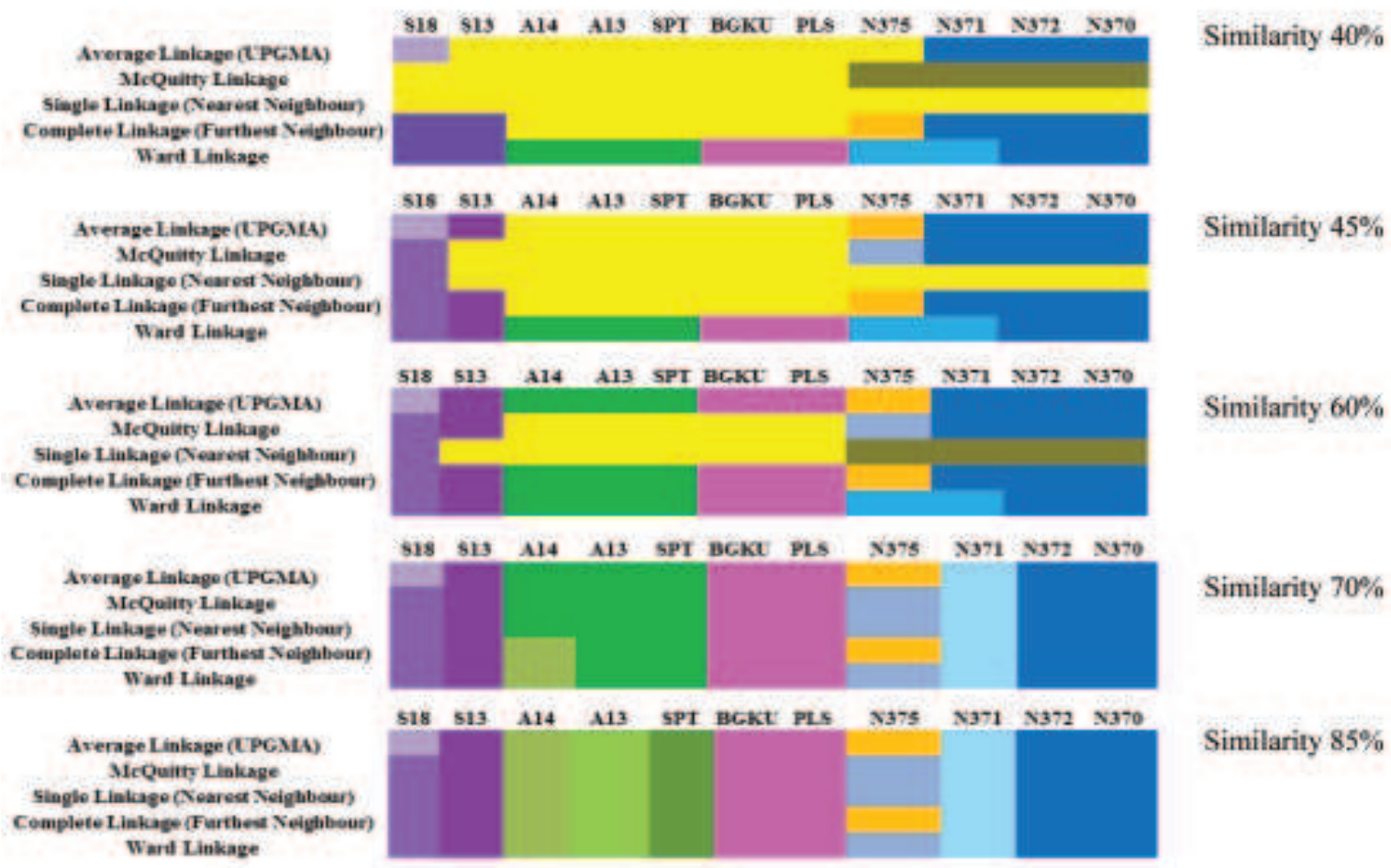

Gambar 4. Peta warna pembentukan kluster yang disusun berdasarkan dendrogram dari masingmasing metoda hierarchical cluster analysis

Warna yang sama menunjukkan kluster yang sama, misalnya S18 memiliki warna yang sama dengan S13, maka keduanya dianggap sebagai satu kluster. Warna yang berbeda pada tingkat kemiripan (similarity) yang lebih tinggi dianggap berbeda kluster. Apabila sebelumnya (pada tingkat kemiripan yang lebih rendah) berasal dari satu kluster, maka keduanya adalah sub kluster. Contoh, S13 dan S18 merupakan satu kluster pada tingkat kemiripan 40\% (warna ungu) dengan metoda Complete Linkage, keduanya akan menjadi sub kluster pada tingkat kemiripan $45 \%$ dengan metoda yang sama.

Tabel 2. Nilai similarity matrix dari analisis korelasi terhadap sebelas profil protein T.evansi

\begin{tabular}{|c|c|c|c|c|c|c|c|c|c|c|c|}
\hline & \multicolumn{11}{|c|}{ Correlation between Vectors of Values } \\
\hline & 813 & 818 & A14 & A13 & $\mathrm{SPT}$ & EGKU & PLS & N371 & $\mathrm{N} 372$ & N375 & N370 \\
\hline 813 & 1,000 & .244 & $.42 \overline{0}$ &, 089 &, 145 &, 355 & $28 \overline{6}$ &, 097 &,- 101 & $.00 \overline{7}$ &,- 101 \\
\hline 818 & .244 & 1,000 & .183 &,$- 14 \bar{b}$ &,- 090 & .258 & .183 &,- 047 &,- 468 &,- 151 &,- 468 \\
\hline A14 & .426 & , 183 & 1,000 & .458 &, 352 & .238 & .190 & $-16 \bar{i}$ &,- 278 &, $04 \bar{\imath}$ &,- 278 \\
\hline A13 &, 089 &,$- 14 \overline{6}$ &, 458 & 1,000 & .458 & $.19 \overline{\mathrm{B}}$ &, $14 \bar{\imath}$ &,- 080 &,$- 046 \overline{0}$ & 379 &,$- 04 \overline{1}$ \\
\hline SPT &, 145 &,- 090 &, 352 & .458 & 1,000 &, 068 &, 190 & -167 &,- 137 &, 320 &,- 137 \\
\hline EGKU &, 355 &, 258 &, 238 & .196 &, 068 & 1,000 & 919 & .175 &,- 089 & .258 &,- 089 \\
\hline PLS & $28 \overline{6}$ & 183 & 190 & $.14 \bar{\imath}$ & 190 &, 919 & 1,000 & 111 & ,004 & 183 &, 004 \\
\hline N371 &, 097 &,$- 04 \bar{\imath}$ & $-1 \bar{b} \bar{l}$ &,- 080 & $-1 \bar{b} \bar{T}$ & .175 & 111 & 1,000 & ,459 & .421 & .459 \\
\hline N372 &,- 101 &,- 468 &,- 278 &,$- 04 \bar{b}$ & $-13 \bar{r}$ & -,, 089 & ,004 & .459 & 1,000 & .007 & 1,000 \\
\hline N375 &, 007 & -151 &, 047 &, 379 &, 320 &, 258 &, 183 & .421 &, 007 & 1,000 &, 007 \\
\hline N370 & -101 &,- 468 &,- 278 &,$- 04 \overline{6}$ & $-13 \bar{t}$ &,- 089 &, 004 & .459 & 1,000 &, 007 & 1,000 \\
\hline
\end{tabular}

This is a similarity matrix

dan A13 berdekatan dengan SPT (Gambar 3.F). Sebaliknya dengan HCA pada tingkat kemiripan $72 \%$, dendrogram yang dihasilkan oleh keempat metoda bersesuaian dengan MDS dan densitogram, sedangkan metoda Single Linkage tidak dapat memisahkan A13 dan SPT dengan A14 (Gambar 3.A - E).

Selanjutnya, apabila tingkat kemiripan diturunkan pada $70 \%$, hanya dendrogram yang dihasilkan dengan metoda Ward Linkage dan 
Complete Linkage yang tetap mengelompokkan A13 dengan SPT, BGKU dengan PLS serta N370 dengan N372. Costas et al. (1987) menyatakan bahwa kemiripan diatas $70 \%$ dianggap cukup tinggi sedangkan $<65 \%$ dianggap rendah untuk dendrogram berdasarkan profil protein pada SDS PAGE. Pada perbandingan secara bertahap ini, dendrogram hasil analisis dengan metoda Ward Linkage dan Complete Linkage lebih konsisten dan bersesuaian dengan profil protein dari SDS PAGE dan densitogramnya serta hasil analisis MDS.

Berdasarkan profil protein, densitogram dan nilai similarity matrix, isolat T.evansi N371 lebih dekat dengan N375 (Gambar 2.C.3) dibanding A13 dan SPT (Gambar 2.C.1 dan 2.C.4). Nilai matrix similarity (Tabel 2) antara isolat N375 dengan N371 adalah 0,421 sedangkan nilai matrix similarity isolat N375 dengan A13 dan SPT adalah 0,379 dan 0,320 (Tabel 2). Hasil analisis dengan MDS juga terlihat bahwa N375 lebih dekat dengan N370, N372 dan N371 serta terdistribusi pada satu bidang yang sama yaitu dimensi 2 (Gambar 3.F). Dengan demikian maka isolat N371 dan N375 akan berada dalam satu kluster dengan N372 dan N370 tetapi memiliki kemiripan pola pita protein yang sangat rendah. Dendrogram yang menempatkan N375, N371, N370 dan N372 dalam satu kluster (yaitu kluster NTT) adalah hasil analisis dengan metoda Ward Linkage, McQuitty Linkage, dan Single Linkage. Disebut kluster NTT karena keempat isolat T.evansi tersebut semuanya berasal dari Sumba Timur, Provinsi NTT.

Isolat N371 dan N375 memiliki pola pita yang lebih dekat dengan isolat N370-N372 sehingga pada dendrogram akan dikelompokkan dalam satu kluster pada tingkat kemiripan 15\% dengan metoda Ward Linkage, 40 - 45\% dengan McQuitty Linkage dan 60\% dengan Single Linkage. Sebaliknya metoda Average Linkage (UPGMA) dan Complete Linkage tidak pernah mengelompokkannya dalam satu kluster pada beragam tingkat kemiripan. Apabila ditinjau dari sisi pembentukan leaves dalam kluster NTT berdasarkan nilai similarity matrix, maka dendrogram dengan metoda McQuitty Linkage dan Single Linkage lebih tepat. Sebaliknya apabila ditinjau berdasarkan tingkat kemiripan pola pita protein secara keseluruhan (densitogram, profil protein dan MDS) antara N371 dan N375 dengan N372 dan N370 yang sangat rendah, maka metoda Ward Linkage dan McQuitty Linkage lebih tepat.

Berdasarkan densitogram, MDS dan nilai similarity matrix, maka pola pita protein isolat A14 lebih dekat kepada A13 dan SPT yaitu 0,458 dan 0,352. Hal tersebut sejalan dengan hasil overlay atau superimposed pada ketiga densitogramnya (Gambar 2.C.2). Dendrogram yang dihasilkan dengan 4 metoda selain Single Linkage dapat menggambarkan pembentukan kluster tersebut dimana leaf dari A14 terpisah dengan A13 dan SPT. Di antara keempat dendrogram tersebut hanya dendrogram yang dihasilkan oleh metoda Ward Linkage dan Complete Linkage yang lebih tepat karena menyatukan A14, A13 dan SPT dalam satu kluster (Kluster Kalimantan) dengan tingkat kemiripan 40\%. Hal demikian masih dapat diterima mengingat Chae-Yoon et al. (2002) dapat mengelompokkan beberapa galur Vibrio sp. yang membedakan antara patogenik dan tidak patogenik dengan UPGMA pada tingkat kemiripan $56 \%$.

Selanjutnya, menempatkan isolat BGKU, PLS, A14, A13 dan SPT dalam satu kluster pada tingkat kemiripan $40-60 \%$ atau $40-65 \%$ sebagaimana ditetapkan oleh keempat metoda tersebut (Complete Linkage, Average Linkage, McQuitty Linkage, dan Single Linkage) dinilai tidak tepat. Hal demikian disebabkan karena profil protein isolat BGKU dan PLS sangat jauh berbeda dengan profil protein isolat A14, A13 dan SPT sebagaimana juga berdasarkan overlay densitogram (Gambar 2.B dan 2.C), nilai similarity matrix (Tabel 2) dan MDS (Gambar 3.F). Dengan demikian metoda Ward Linkage cenderung lebih dapat diterima karena memisahkan isolat BGKU dan PLS dengan isolat A14, A13 dan SPT ke dalam dua kluster yang berbeda. Dendrogram yang dihasilkan dengan metoda Ward linkage hanya menempatkan BGKU, PLS, A13, A14 dan SPT dalam satu kluster pada tingkat kemiripan $15 \%$. Hal ini membuktikan bahwa BGKU dan PLS memiliki kemiripan profil protein yang sangat rendah dengan A14, A13 dan SPT.

Isolat T.evansi $\mathrm{S} 13$ dan $\mathrm{S} 18$ berasal dari daerah yang sama tetapi memiliki profil yang jauh berbeda. Berdasarkan nilai similarity matrix dan MDS diperkirakan S13 lebih dekat dengan S18 dan keduanya lebih dekat pada BGKU dan PLS dibanding dengan A13, A14 dan SPT. Penempatan isolat S13 dan S18 ke dalam satu kluster menggambarkan bahwa kedua 
isolat tersebut berasal dari satu kluster secara geografis meskipun kemiripan keduanya sangat berbeda. Fakta ini mengindikasikan adanya kemungkinan bahwa keragaman isolat T.evansi di wilayah Banten sangat tinggi. Selanjutnya S13 dan S18 akan membentuk kluster dengan BGKU dan PLS dengan tingkat kemiripan yang rendah pula. Pada tahap terakhir, keempat isolat tersebut akan membentuk satu kluster dengan A14, A13 dan SPT sebagaimana hal ini dapat terlihat pada analisis MDS yang menunjukkan sebaran pada satu bidang yang sama yaitu dimensi 3 (Gambar 3.F).

Dendrogram yang paling tepat dalam menggambarkan pembentukan kluster secara agglomerative dari S13, S18, BGKU, PLS, A14, A13 dan SPT adalah Ward Linkage. Demikian pula apabila ditinjau dari pengelompokan berdasarkan asal usul isolat T.evansi tersebut secara geografis, maka dendrogram dengan metoda Ward Linkage dapat mengakomodasi informasi tersebut dalam pembentukan klusternya. Berdasarkan bukti tersebut, metoda Ward Linkage merupakan metoda yang paling sesuai digunakan dalam analisis keragaman hayati terhadap kesebelas isolat T.evansi dari Indonesia. Hal ini disebabkan karena metoda tersebut mampu mengelompokkan masing-masing isolat ke dalam empat kluster yang menggambarkan lokasi geografis dari asal usul isolat tersebut (Gambar 1). Isolat N370, N372 dan N371 serta N375 merupakan satu kluster yang berasal dari NTT. Isolat A14, A13 dan SPT dikelompokkan dalam satu kluster yang berasal dari Kalimantan dan isolat PLS dengan BGKU juga ke dalam satu kluster yang berasal Sumatra. Demikian juga isolat S13 dan S18 berada dalam satu kluster yang berasal dari Banten.

Pada metoda Ward Linkage, isolat N375 dan N371 meskipun ditempatkan dalam satu kluster tetapi kemiripan keduanya maksimum hanya $60 \%$. Hal ini menunjukkan keduanya merupakan isolat yang berbeda meskipun serumpun. Dengan demikian isolat T.evansi dari NTT tersebut merupakan tiga populasi yang berbeda yaitu N370-N372, N371 dan N375. Demikian pula halnya dengan kluster dari Banten, kedua isolat tersebut dapat dipandang sebagai dua populasi yang berbeda karena rendahnya kemiripin pola pita protein.

Hasil yang diperoleh dari penelitian ini berbeda dengan beberapa peneliti yang menggunakan teknik analisis serupa. Singh (2008) menyatakan bahwa Average Linkage, Complete Linkage, dan Ward Linkage merupakan tiga metoda yang paling banyak digunakan dan direkomendasi untuk pembentukan dendrogram. Costas et al. (1987) telah menggunakan UPGMA (Average Linkage) untuk dapat mengklasifikasikan Mycoplasma mycoides berdasarkan pola proteinnya. Berber dan Berber (2006) juga telah menggunakan metoda Average Linkage untuk pengelompokan Bacillus sp. yang alkalifilik fakultatif. Demikian pula Delamare et al. (2002) juga telah menggunakan UPGMA untuk melakukan analisis profil protein dari Aeromonas sp. yang berkorelasi dengan data biokimia dan genetis. Sebaliknya, Yim dan Ramdeen (2015) telah mendemonstrasikan bahwa Average Linkage merupakan metoda terbaik pada data bilingual yang mengelompokkan data penggunaan tiga bahasa pada sekelompok pengguna. Sebaliknya, Berber dan Yaşar (2011) menyatakan bahwa Average Linkage tidak cukup baik untuk membedakan kultivar kacang turki (turkish bean) berdasarkan data profil proteinnya pada SDS PAGE. Para peneliti tersebut hanya menggunakan satu metoda untuk pembentukan dendrogram.

Analisis pada penelitian ini dilakukan dengan membandingkan lima metoda HCA. Metoda Ward Linkage terbukti merupakan yang paling tepat dan terbaik digunakan untuk pembentukan dendrogram pada analisa keragaman hayati terhadap sebelas isolat T.evansi dari Indonesia. Hal demikian serupa dengan beberapa laporan peneliti terdahulu pada berbagai jenis penelitian. Hands dan Everitt (1987) telah membandingkan enam metoda HCA dan menyatakan metoda Ward Linkage secara keseluruhan merupakan metoda terbaik khususnya apabila proporsi kelompok hampir seimbang. Singh (2008) menyatakan bahwa Ward Linkage juga merupakan metoda terbaik pada studi ekologi untuk analisis kluster pada data komunitas bentos di sungai. Metoda Ward Linkage juga telah digunakan oleh Telleria et al (2010) untuk menganalisis 26 isolat Trypanosoma cruzi berdasarkan variabilitas proteomiknya. Adapun Saraçli et al. (2013) juga telah menyebutkan bahwa metoda Ward Linkage telah dikenal menjadi metoda yang akurat digunakan dalam berbagai kondisi. 


\section{SIMPULAN DAN SARAN}

Metoda Ward Linkage merupakan metoda yang sesuai untuk HCA karena mampu membentuk 4 kluster T.evansi sekaligus menggambarkan keragamannya sesuai dengan analisis multidimensional scaling maupun overlay dari densitogram profil protein. Sebelas isolat T.evansi dari beberapa daerah di Indonesia dapat dikelompokkan 4 kluster sesuai dengan asal usul geografisnya. Disarankan untuk menguji metoda Ward Linkage menggunakan data profil protein dengan jumlah isolat T.evansi yang lebih banyak untuk mengevaluasi konsistensinya.

\section{DAFTAR PUSTAKA}

Berber Ý, Berber. 2006. Numerical analysis of SDS-PAGE protein patterns of facultative alkaliphilic Bacillus species isolated from Lake Van, Turkey. FEB 15(5): 409-416.

Berber Ý, Ekin S. 2008. Discrimination and numerical analysis of human pathogenic Candida albicans strains based on SDS PAGE protein profiles. African J. Biotech. $7(4): 425-429$.

Berber Ý, Yaşar F. 2011. Characterization of Bean (Phaseolus vulgaris L.) cultivars grown in Turkey by SDS PAGE of seed proteins. Pakistan J. Bot. 43(2): 1085-1090.

Chae-Yoon L, Hong Y, Ryu J, Kim YR, Oh SS, Lee SH, Hwang IG, Kim HY. 2012. Detection and Identification of Vibrio Species Using Whole-Cell Protein Pattern Analysis. J. Microbiol. Biotech. 22(8): 1107-1112.

Costas M, Leach RH, Mitchelmore DL. 1987. Numerical Analysis of PAGE Protein Patterns and the Taxonomic Relationships within the Mycoplasma mycoides Cluster. J Gen. Microbiol. 133: 3319-3329.

Delamare APL, Artico LO, Grazziotin FG, Echeverrigaray S, da-Costa SOP. 2002. Total protein electrophoresis and RAPD fingerprinting analysis for identification of Aeromonas at the species level. Brazilian J. Microbiol. 33: 358-362.

De-Menezes VT, Queiroz AO, Gomes MAM, Marques MAP, Jansen AM. 2004. Trypanosoma evansi in inbred and Swiss-
Webster mice : distinct aspects of pathogenesis. Parasitol. Res.. 94:193-200.

Hands S, Everitt B. 1987. A Monte Carlo study of the recovery of cluster structure in binary data by hierarchical clustering techniques. Multivar. Behavior. Res. 22: 235-243.

Laemmli UK. 1970. Cleavage of structural proteins during the assembly of the head of bacteriophage T4. Nature 227: 680-685.

Laha R, Sasmal NK, Bandyopadhyay S. 2008. Comparative polypeptide profiles of whole cell lysate antigens of Trypanosoma evansi isolated from three different hosts of eastern India. J. Protozool. Res. 18: 11-16.

OIE (Office International des Epizooties). 2012. Trypanosoma evansi infection (Surra), OIE Terrestrial Manual 2012, Chapter 2.1.17, pp.1-15. France.

Pavel AB, Vasile CI. 2012. PyElph - a software tool for gel images analysis and phylogenetics. BMC Bioinform. 13:9.

Saraçli S, Doðan N, Doðan I. 2013. Comparison of hierarchical cluster analysis methods by cophenetic correlation. J Inequal Appl. 2013: 203. doi:10.1186/1029-242X-2013-203.

Singh V, Singh A, Chhabra MB. 1995. Polypeptide profiles and antigenic characterization of cell membrane and flagellar preparations of different stocks of Trypanosoma evansi. Vet. Parasitol. 56: 269-279.

Singh W. 2008. Robustness of three hierarchical agglomerative clustering techniques for ecological data. University of Iceland [MSc Thesis].

Sivajothi S, Rayulu VC, Reddy BS, Reddy BVS. 2015. Polypeptide Profiles of Whole Cell Lysate Antigens of Trypanosoma evansi Isolated From the Dogs by SDS-PAGE. $J$ Dairy Vet. Anim. Res. 2 (5) : 00047. DOI: 10.15406/jdvar.2015.02.00047.

Subekti DT, Sawitri DH, Wardhana AH, Suhardono. 2013. Pola Parasitemia dan Kematian Mencit yang diinfeksi T.evansi Indonesia. JITV 18(4): 274-290.

Tahmourespour A, Nabinejad A, Shirian H, Ghasemipero N. 2013. The Comparison of Proteins Elaborated by Streptococcus 
mutans Strains Isolated from Caries Free and Susceptible Subjects. Iranian J. Bas. Med. Sci. 16(4) : 656-660.

Telleria J, Biron DG, Brizard JP, Demettre E, Séveno M, Barnabé C, Ayala FJ, Tibayrenc M. 2010. Phylogenetic character mapping of proteomic diversity shows high correlation with subspecific phylogenetic diversity in Trypanosoma cruzi. Proc. Nat. Acad. Sci. (PNAS) 107(47): 20411-20416.
Uche UE, Ross CA, Jones TW. 1992. Identification of the surface components of Trypanosoma evansi. Res. Vet. Sci.. 53: 252 253.

Yim O, Ramdeen KT. 2015. Hierarchical Cluster Analysis: Comparison of Three Linkage Measures and Application to Psychological Data. Quant. Meth. Psych. 11(1): 8-21. 